Clayton Hazvinei Vhumbunu

Post-Doctoral Research Fellow in International Relations, School of Social Sciences, University of KwaZulu-Natal (UKZN), Durban, South Africa . Email: cvhumbunu@gmail. com; Vhumbunuc@ukzn. ac.za

DOI: https://dx.doi. org/10.18820/24150509/ JCH43.v2.8

ISSN 0258-2422 (Print) ISSN 2415-0509 (Online) Journal for Contemporary History

2018 43(2):134-159

(c) Creative Commons With Attribution (CC-BY)

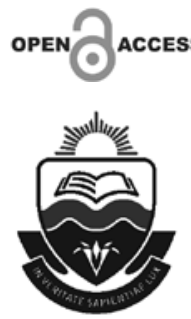

\section{REFLECTING ON THE ROOT CAUSES OF SOUTH SUDAN SECESSION: WHAT CAN OTHER AFRICAN LEADERS LEARN?}

\begin{abstract}
The secession of South Sudan from Sudan in 2011 remains a significant development on Africa's political landscape. It will continue to shape and influence the direction of secessionist conflict management and resolution dynamics on the continent. This is not because it was the first secession case in Africa given the fact that, previously, Eritrea had seceded from Ethiopia in 1993. Rather, unlike the Eritrea-Ethiopian case, the South Sudan secession case has a unique and edifying pre- and postcolonial historical narrative whose instructive value to post-colonial governments and governance processes in Africa remains remotely studied and utilized. Despite numerous research on pre-secession Sudan, there has been limited constructively aligned research that unravels the root causes of South Sudan secession, and sift lessons that can be progressively applied to either avoid and prevent secession in Africa, or constructively manage secessionist pressures in a way that retains peace, stability and national development. Using secondary data analysis, this paper explores the root causes of South Sudan secession with a view to discern and deduce adaptable and appropriate lessons that can be learnt by African governments at a time when secessionist conflicts are on the rise.
\end{abstract}

Keywords: South Sudan; Sudan; secession; conflict; conflict resolution; conflict management.

Sleutelwoorde: Suid-Soedan, Soedan; sesessie; konflikbeslegting; konflikbestuur 


\section{INTRODUCTION}

A very disturbing fact in African politics has been the emergence of secessionist movements across the continent. Some of these appear dormant and weak in terms of capacity, followership and international recognition, whilst others are gaining traction and strength by the day, thereby posing serious threats to national and regional peace, security and stability. Experiences of countries that have undergone secessionism remain valuable in presenting lessons of secessionist conflict prevention, management, resolution and transformation in Africa. This article analytically traces the root causes of the Sudanese conflict that consequently led to secession. Given the complexity of the Sudanese conflict, the article explores the various multiple-causation explanations of events, incidents, political processes and outcomes that shaped the course and evolution of the Sudanese conflict. In doing so, a three-phased approach is adopted in a historical analysis, viz; Pre-colonial phase (pre-18 ${ }^{\text {th }}$ Century - 1820), Colonial phase (18201955), and the Post-colonial phase (1956-2011). In the process, possible lessons that can be of governance value to African countries are identified.

\section{THE GEOGRAPHY AND SOCIOLOGY OF SUDAN}

The name "Sudan" was derived from "bilad-al-Sudan", an expression originated by the medieval Arab historians, geographers, and travellers to mean, "the land of the blacks", in reference to the land in Africa south of the Sahara Desert, which straddles from the Atlantic Ocean to the Ethiopian plateau (Voll 1978). At independence on 1 January 1956, Sudan was geographically the largest in Africa, covering an area of 957, 500 square miles (about 2,4 million $\mathrm{km}^{2}$ ) bordering Chad, the Central African Republic, Egypt and Libya, Eritrea, Ethiopia, Kenya and Uganda. Given its sheer size, the state merged different cultures and regions, in East, West, South and North Africa. 
Figure 1: $\quad$ Map of Sudan with borders adopted at independence in 1956

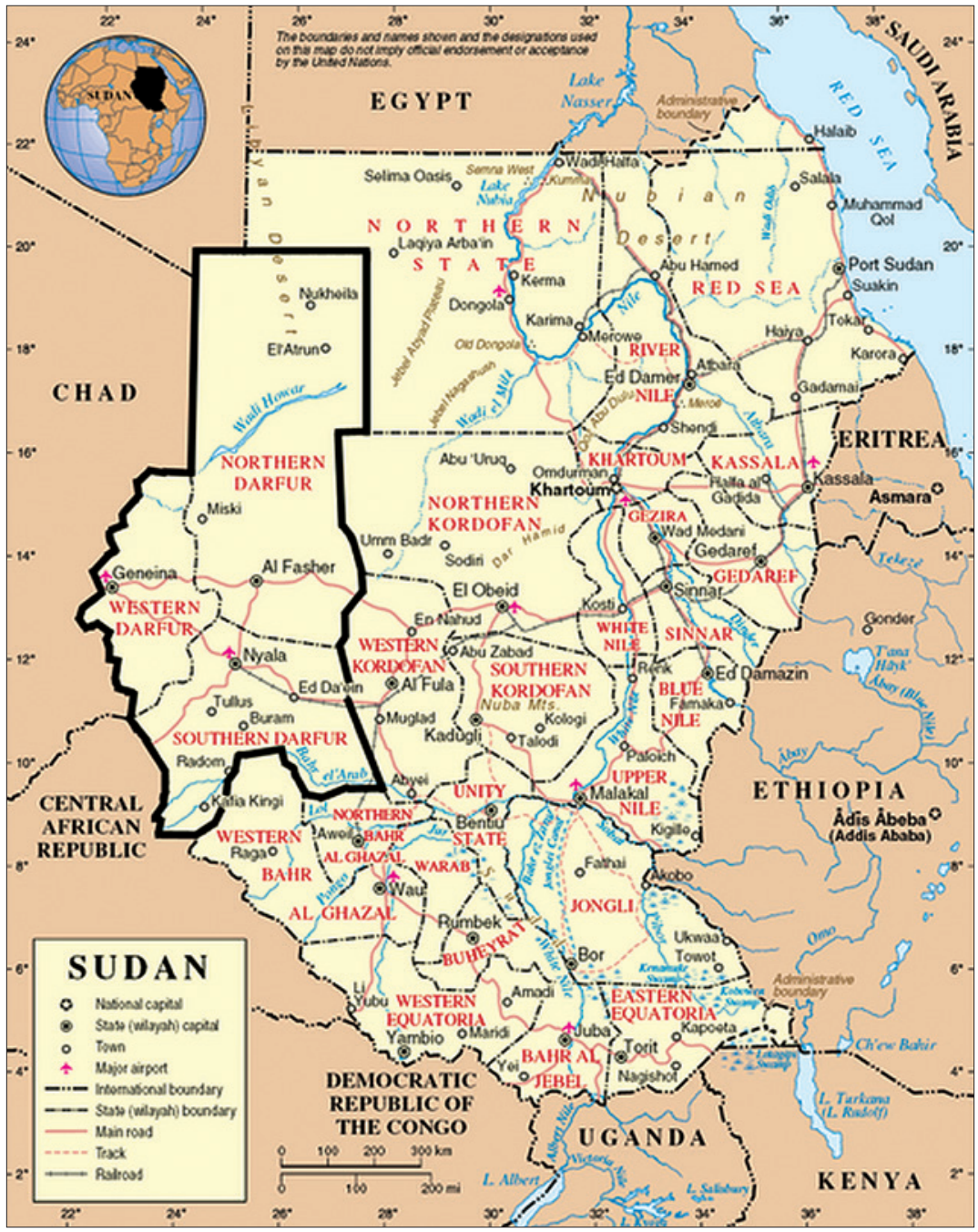

Source: United Nations (2015) 
In terms of sociology, the 1955 population census in Sudan revealed that the total population in Sudan was 10252536 (just over 10 million), with 7469400 being northerners, whilst 2783136 were living in the south (O'Ballance 2000). The indigenous African Sudanese (whose mother tongue was other than Arabic) constituted $69 \%$ of the population, whilst Arab Sudanese constituted $31 \%$ of the population (Voll 1978). The same census also revealed that there were 56 ethnic groups in Sudan, further divided into 597 sub-groups with around 115 languages being spoken across the country (Voll 1978). About $70 \%$ of the national population were Muslims, 5\% being Christians, and 25\% practicing traditional African religions (see Voll 1978:5; Musa 2010:555; Okojie 2013:421-422).

The general distribution was that Arabs, Arabized Nubians, and the Beja were concentrated in the north of Sudan, whilst Negroids and Nilotic tribes (Dinka, Nuer, Shilluk and Anuak), the Nilo-Hematic and the Sudanic tribes were in the western, eastern and southern parts of Sudan (Okojie 2013; Voll 1978). Thus, Sudan is usually referred to as, "the fault line of Africa" as it constitutes the frontier between the Muslim north and the Christian south regions (Voll 1974: 85). From all this, one can note that Sudan was a melting pot of people with different ethnic, religious, cultural, racial and linguistic distinctions. Such diversity would require effective good governance for unity, cohesion, peaceful co-existence and stability.

\section{PRE-COLONIAL SUDAN (PRE-18 ${ }^{\text {TH }}$ CENTURY - 1820)}

Before colonialism, Sudan was a collection of kingdoms and tribally organized communities. It should be noted, however, that prior to colonization, identity was not at the centre of conflict in Sudan. The coming in of colonialism, ignited divisions bordering on identity as a divide and rule modus operandi.

\section{COLONIAL SUDAN (1821-1955)}

The colonial history of Sudan, punctuated by two main colonial regimes, namely the Turko-Egyptian rule (1821-1882) and the Anglo-Egyptian Condominium (1899-1956), had a very influential role in terms of shaping post-colonial conflict dynamics. Kebbede (1997:16) argues that, "Sudan's North-South conflict owes its genesis to the colonial past". This will be explained further in later sections of this article.

The significance of the Turko-Egyptian colonial government (1821-1882) was that it sowed seeds of divisions amongst Sudanese necessitated by four fundamental dynamics, namely (a) colonial administrative structure, (b) establishment of indirect rule, (c) religion, and (d) slave trade. The indirect rule, 
administered through traditional chiefs as the modus operandi after the division of Sudan into regional provinces (ruled by general governors), and smaller administrative units largely on tribal lines, was divisive.

In terms of religion, the Turko-Egyptian colonial administration revised the Sudanese legal system and introduced commercial and criminal codes applied in secular courts of law, whilst encouraging orthodoxy religious practices across the Ottoman Empire. According to Metz (1991), this, "reduced the prestige of the qadis (Islamic judges) whose Sharia courts were confined to dealing with matters of personal status". Naturally, this was despised by the Muslims in Sudan as it was against their religious practices and faith. The official language of communication was Turkish, and later switched to Arabic.

The Turko-Egyptian's 60 years of colonial rule presided over an era of heightened slave trade, which entrenched deep hatred for the north by the south Sudanese people. The southerners consisted of the Nilotic peoples, mostly the Dinka, Nuer, and Shilluk who had settled in the south as tribal migrants in the $10^{\text {th }}$ century and established their traditional monarchs there were victims of slavery. As Metz (1991) reckons, "[a]nnual raids resulted in the capture of countless thousands of southern Sudanese, and the destruction of the region's stability and economy". Kebbede (1997) puts the figure higher, stating that around two million southern Sudanese, mostly Dinkas, were sold as slaves to the Arabs, Europeans, and Egyptians during the Turko-Egyptian rule. Other scholars have argued that northern Sudanese were complicit in slave trade practice, through collaborating with the Turko-Egyptian rulers to sell southerners to Arab slave markets.

What can be noted is that all this had the net effect of instilling and entrenching prejudices, stereotypes, mistrust and hostilities that would characterise relations between northerners (Afro-Arabs) and southerners (black Africans). Future governments then had a rather herculean task of reconfiguring these relations.

Although the Turko-Egyptian 60-year colonial reign ended in 1881, after it was overthrown by a movement led by Muhammad Ahmad ibin Abdallah (the al-Mahdi or the "the Rightly Guided One"), in 1881, its policies widened the cracks left by its predecessors. By retaining the centralized system of governance and the administrative structure that had been established by the Turko-Egyptian rulers; abolishing civic education and replacing it with Quáranic schools (Khalwas); abolishing civil laws and replacing them with Islamic Sharia laws and other traditional/customary conventions; perpetuating slave trade; abolishing the Governor General position and replacing it with the position of the Caliphate; and replacing Provincial Commissioners with Regional Governors (Waalis) (Kebbede 1997; Government of Sudan 2015), the al-Mahdi widened north-south fissures and intensified hostilities between and among Sudanese. 
The Anglo-Egyptian Condominium, which reigned from 1899 to 1956, is considered by many scholars as a key part of the complex and complicated historical roots of the conflict between northern Sudanese and southern Sudanese (see for instance; Ahmad 2010; Daly 2003; Okojie 2013; Powell 2007). This was a "colonial joint venture", as one may put it in modern corporate jargon, of Great Britain and Egypt facilitated through the Anglo-Egyptian Condominium Agreement ("Agreement for the Administration of the Sudan") signed in Egypt on 19 January 1899 by Lord Cromer (the British CounselGeneral in Egypt) and Boutros Ghali Pasha (the Egyptian Minister of Foreign Affairs).

The Anglo-Egyptian Condominium designed and implemented policies that deepened and widened the regional, ethnic and religious cleavages, which had existed in Sudan, which gave rise to serious conflict. In an attempt to respond to a self-imposed question, "What is the problem of Southern Sudan (conflict)?" Alier in Wai (1973:11), points sharply to the colonial fingerprints and footprints of the Anglo-Egyptian Condominium, albeit acknowledging other relevant factors,

"Some of the aspects of the problem [conflict] are historical, others are cultural and yet others are economic. Some of it has become psychological. But the problem was essentially one of neglect by the British administration between 1898 and 1952 to develop the Southern Sudan."

Whilst from a geo-strategic point of view, the British really wanted a united Sudan so that they continue to control the Nile Waters and the strategic Suez Canal - a key trade route to India and the Far East (see also Deng 1994; Metz 1991), and also ensure stability in order to exploit the abundant natural resources in Sudan such as gold, chrome ore, iron ore, copper, mica, silver, tungsten, zinc, and hydro-power and agriculture potential along the Nile Rivers (CIA World Factbook, 2015) in reality the Condominium policies were not pro-unity.

The Anglo-Egyptian Condominium policies included the Indirect Rule Policy, the Southern Policy, and the Policy of Arabization and Islamization, which all contributed differently as sources of conflict. For instance, the system of indirect rule in Sudan whereby the shaykhs would preside over villages, tribes and districts had to oversee local area administration in northern Sudan, whilst tribal chiefs were in charge of the same in the south; created tribalism as ethnic groups began to view themselves as separate nationalities, and exclusively owning, and therefore preventing any access to, local resources such as land, water and grazing pastures by "outsiders". Such was the effect of indirect rule in Sudan.

On the other hand, the Southern Policy, which was implemented through a series of immigration laws, trade laws, language policy and administrative regulations in the 1920s and 1930s, had negative effects on national unity and cohesion. It created two separate administrative systems for the south 
(categorized as "Blacks"/"Negroids"/"pagans"), and the other for the "Arabic"/"Middle-Eastern"/"Islamic" north in order to reduce and avoid contact and communication between these two regions in pursuit of three fundamental colonial objectives, viz; (a) preventing the spread and influence of Arab and Muslim southwards; (b) preparing the southern region from eventual integration into the British East Africa Federation/Union; and (c) controlling the sources along the length of the Nile (see Ahmad 2010; Arkell 1983; Deng 1994; Holt and Daly 2014; Kebbede 1997; Wei 1980). This was a "dismemberment project" or "fragmentation initiative", which created raw materials for eventual secession in 2011.

Other Southern Policy laws, such as the Closed Districts Order/Ordinances were passed between 1920 and 1946; the Passports and Permits Ordinances, the Passports and Licences Act of October 1922, and the Permits to Trade Order of 1925; all introduced stringent measures that erected an "iron curtain" and made it extremely difficult for Sudanese to travel northwards or southwards for trade, employment and other economic exchanges. In addition, other legislative frameworks such as the Traditional Chiefs' Courts Ordinance and the Native Court Ordinance promulgated in 1931 and 1932 respectively established chiefs' and native courts that ended up creating jurisdictional conflicts. For example, the Ngok Dinka in Abyei and Northern Province of Kordofan were all put under the jurisdiction of chiefs' courts in the southern region, which later became a future source of conflict and/or contention up to the present day.

Through the same Southern Policy, the British built roads, rail lines, schools, agricultural schemes, telecommunications, postal systems and other development projects, "to link important areas of economic interest" along the White Nile, to control Upper Nile in the north and central region whilst, "very few economic, social and administrative structures were built in the South" (Kebbede 1997:17). This marginalized the south and ensured that mostly the educated northern Arabs and Muslims were beneficiaries of created opportunities.

Without doubt, the policy of Arabization and Islamization, which was purportedly meant to reverse the Southern Policy in 1946 as a result of rising tides of nationalism, had its own excesses. For instance, attempts to reopen the closed north-south boundary and forcefully unite the two regions into a single administration within which Arabic would be the lingua franca, and Islam the single religion, had its own ramifications. Although the formal north-south administrative unification decision was agreed and accepted by both northern and southern leaders at the Sudan Administrative Conference (SAC) of 1946, and later endorsed at the Juba Conference, the form it took (Arabization and Islamization) was abhorred by the southerners. The Arabization of the education policy was discriminatory to mostly southerners. A case in point being admission at Gordon Memorial College [a Khartoum-based training institute for bureaucracy 
established in 1902], privileged those who were male, Muslims, Arab-speaking, Arabs, and of "high status" (Sharkey, 2003). Thus, Arab, Arab culture, Arab language and Islam all had been elevated to superior status with the southern ethnic languages regarded as inferior.

In a nutshell, the colonial policy pronouncements and promulgated legislations in Sudan created the Afro-Arab, Muslim-Christian, and north-south dichotomy instead of embracing diversity as a source of strength. Given this background, the development of a shared national consciousness in Sudan was going to be an insurmountable task for post-colonial governments to address grievances bordering on, inter alia, both perceived and real; ethnic hostilities, religious intolerance, political subjectivities, regional inequalities, injustices, social identity, racial animosity, racial divisions, marginalization and resentments.

\section{PRE-INDEPENDENCE ARRANGEMENTS IN SUDAN}

What needs to be acknowledged is the fact that the transition from colonialism to independence was not handled as delicately as it was supposed to be. The colonial administration needed to make efforts to prepare for a smooth handover-takeover, especially considering the political context of colonial Sudan.

Instead, when the British took initiatives to prepare for Sudanese independence in the mid-1940s following in response to the rise in Islamic nationalism launched mostly from northern Sudanese provinces, which detested indirect rule, policies of the centralized Condominium government Khartoum (Metz, 1991), their initiatives did not reflect the expectation for national unity and integration. Engagements made through platforms such as the Juba Conference of 1947 and deliberations in the Sudan National Legislative Assembly (NLA) that was established in 1948 and those of the Constituent Assembly; all reflect failure of the British colonial administration to restore the much needed trust between the southerners and northerners towards each the idea of unifying Sudan. Khalid in Hopkins (2007:191) also notes that the minutes of the Juba Conference, "are replete with expressions of fear, distrust and eloquent objections to NorthSouth Unification", whilst at one time the southerners even petitioned the British authorities stating that in absence of a federation they preferred being administered by a British Foreign Office appointed High Commissioner placed under the United Nations Trusteeship until such a time they were capable of deciding their own future, or else they would resort to alternative options they desired (Johnson 2014:9).

There is also a clear observation that the British colonial administration, through acts of commissions and omissions during the transitional period, between 1953 and 1955, planted seeds of future conflict. Continued calls for 
federalism, equal representation in government and other national institutions by the southerners were not fully addressed. For example, the Sudanization process (or nationalization of jobs through replacing colonial administrators with Sudanese) unfairly and unjustly favoured northerners, who occupied 800 civil service positions compared to 8 occupied by southerners, since most southerners could not get civil service positions as they were disadvantaged by the replacement of English with Arabic as the official language of communication, and also lacked experience and requisite qualifications (Ahmad 2010; Johnson 2014; Abusharaf 2013; Ylonen in Oberg and Ostrom, 2008). Hence, they called for the Africanization of the civil service, national army and police, especially in the south (Badal 1976). The above thus became some of the causes of the outbreak of civil war in Sudan. Johnson (2011:27) notes,

"There was thus widespread discontent in the South as a result of the outcome of the 1954 elections and the Sudanization process. The rapid increase of Northerners in the South as administrators, senior officers in the army and police, teachers in government schools and as merchants, increased Southern fears of Northern domination and colonization."

This led to the army mutiny in August 1955 when the Equatoria brigade/ corps revolted, sparking the First Civil War in Sudan.

\section{POST-COLONIAL SUDAN}

The Declaration of Independence made unanimously by northern and southern Sudanese political parties on 19 December 1955 promised that federal status would be conferred to the south upon the attainment of national independence. One can note that, however, the post-colonial governments' failure to honour agreements, together with other arising grievances, led to conflicts. The Sudanese post-colonial conflict history was marked by the First Civil War in Sudan (19551972), which led to the Addis Ababa Peace Agreement (1972); the Second Civil War in Sudan (1983-2005), which led to the Comprehensive Peace Agreement (2005); and the Government of National Unity (2005-2011), which led to the secession of South Sudan in 2011.

\subsection{First Civil War in Sudan (1955-1972)}

The First Civil War was sparked by the rebellion in Torit, Equatoria, in August 1955, whereby rebels targeted army garrisons, administrators and merchants who, in their view, personified the northern domination (lyob and Khadiagala 2006).

There is a general consensus amongst scholars, that the key driver of this civil war was the failure of the northern-dominated Sudanese governments to satisfactorily address the southern grievances, chief among them, the issue of 
regional autonomy, against a background of a people that had endured so many years of geographic, political, social and cultural marginalization as well as underrepresentation in national government structures (see Abusharaf 2013; Basha in Raftopoulus and Alexander 2006; Deng 1994; Holt and Daly 2014; Johnson 2014; Khalid 2010; Machar 1995; Metz 1991). Hence, the terms "marginalization", "monopolization", "under-representation", "exclusion", "deprivation", "inequality", "isolation", "domination", "suppression", "oppression", "hegemony", and related descriptions feature prominently in Sudan conflict literature with reference to the north-south relations in the country.

\subsection{Immediate Post-Independence Rule (1956-1958)}

Between 1956 and 1958, Sudan was ruled by a Sovereign Council that was set up in July 1956 to replace Ismail al-Azhari's National Unionist Party (NUP) Government. This was later replaced by a People's Democratic Party (PDP) and the Umma Party (a northern Islamic political party), coalition government following the 1958 elections.

What is more fundamental is how southern question was handled during this period. The southerners continued to be numerically inferior in the National Assembly; hence, they were out-voted whenever the issue of federalism was brought up for consideration. Again, one cannot ignore a series of radical policy measures adopted by the immediate post-independence authorities, including Prime Minister Abdallah Khalil, which were met with disfavour and virtually worsened the north-south relations. For instance, the 1957 Constitutional Committee recommendation for a federal state of South Sudan was rejected, missionary schools were nationalized by the government in 1957, there was Arabization and Islamization of the south, budget allocation was skewed in favour of the north, and budget allocations to southern projects were reduced, as was the case with the financing of the Azande Development Scheme which was reduced during al-Azhari's tenure (O'Ballance, 2000).

\subsection{General Ibrahim Abboud Military Rule (1958-1964)}

Lieutenant-General Ibrahim Abboud, who was the Commander-in-Chief of the Sudan Armed Forces, carried out a military coup on 17 November 1958 and reigned up to October 1964. Like his predecessors, it is clear that he perpetuated a system that entrenched divisions, hostilities and conflict. For example, the policies of Islamization and Arabization in Southern Sudan continued with a view to spread Arab identity, Arabic language, the ideology of Arab cultural supremacy and Arab domination into the southern frontier so as to politically unify Sudan through language and religion (Sharkey 2008, Badal 1990). 
The first Minister of Interior after independence is reported to have said, "Sudan is an Arab country and whoever does not feel Arab should quit" (Deng and Gifford in Kebbede, 1997:18). Over and above this, all political parties were banned, several southern politicians were arrested and some fled to exile. Moreover, the Military Council that was in charge during Abboud's era was unrepresentative in terms of regional balance, given that it had only one Minister in Cabinet, that is, Santino Deng, who was the Minister of Animal Resources. Regional economic development disparities and imbalances were perpetuated despite General Abboud being credited for improving economic growth, industrial capital, developing hydroelectric schemes and irrigation projects (O'Ballance 2000: 25).

Obviously, such actions attracts reactive movements as was the case with the formation of political movements by the southerners to wage a war against injustices, for example, the Sudan-African Closed Districts National Union in 1962 by the trio of William Deng Nhial (the party Secretary General), Joseph Oduho (the party President) and Father Saturnino Lohure (the party patron) who were exiled in Kinshasa, Zaire (Badal 1976; Gurtong 2016; Voll 1978). The party, which was later renamed Sudan African National Union (SANU) in 1963, and merged with other political groupings to form the Land Freedom Army (LFA), and then AnyaNya (which means "snake poison/venom"/ "poisonous insect"/ "poisonous concoction") to wage a guerrilla war against the central Government of Sudan (see Basha in Alexander and Raftopoulus 2006: 11; O'Ballance 2000: 19; Metz 1997: np).

Accordingly, the prolonged conflict between the southerners and government forces, given their fatality as evidenced from the strategies and counter-strategies of burning villages, banditry, insurgency, government infrastructure, torture, and other forms of atrocities, instilled a culture of violence and deep scars among Sudanese. Like any war, it is key to point out that such war experiences nurture combative identities, entrench hostility, divisions and hatred amongst citizens. In assessing General Abboud's tenure, O'Ballance (2000: 25) argues that Abboud's greatest undoing was his inability to unite his subordinates and his failure to resolve the southern problem, referring to the latter as the, "last straw in his downfall".

\subsection{Jaffar Nimeiri Regime (1964-1985)}

When the rule of General Abboud ended in November 1964, it was succeeded by a nine-month transitional government, headed by Sir al-Khatim al-Khalifah at first, then later by Muhammad Ahmad Mahgoub and Sadiq al-Mahdi (all through NUP-Umma Coalitions) before the "May Revolution" and coup of 25 May 1969 brought to power Colonel Jaafar al-Nimeiri as the head of the Revolutionary 
Command Council (RCC) with Babiker Awadallah as the Prime Minister (Fadlalla 2007; Government of Sudan 2015; Johnson 2014; Voll 1978).

One of the greatest undoing of Nimeiri's rule, was the establishment of a one party state (the Sudanese Socialist Party), censorship and military repression, which faced opposition from both northerners (Umma Party, Muslim Brotherhood, Democratic Unionist Party, and Communists) and southerners as evidenced by the failed attempted coup led by Lieutenant Hussein Osman and another by Major Hashim al-Atta, in 1966 and 1971 respectively (Iyob and Khadiagala 2006). His purported willingness and readiness to grant autonomy to the southern region within the framework of a united socialist Sudan as outlined in the June Declaration of 1969 (O'Ballance 2000), has been interpreted by some scholars as being motivated by the desire to consolidate power in Northern Sudan through alliances in the south.

Nevertheless, what cannot be disputed is that Nimeiri's administration made notable attempts to attend to the southern grievances, notably, the Commission of Enquiry of the South (set up to examine the unrest in the south on 7 September 1964); the Khartoum Roundtable Conference of 16-29 March 1965; and the Roundtable Conference Report produced in September 1966. However, in terms of delivery, not much was achieved on the ground in addressing the southerners' grievances. For instance, the Commission of Enquiry's recommendation for a southern autonomy were ignored whilst at the Roundtable Conference - which was also attended by Algeria, Egypt, Ghana, Kenya, Nigeria, Tanzania and Uganda - the Government rejected the southern proposals for a federation and southern referendum to decide on self-determination; and only resolved to give southerners governmental and administrative posts (Kebbede 1997; Iyob and Khadiagala 2006; O'Ballance 2000). On the other hand, the South Sudan Provisional Government (SSPG), formed in 1968 by Aggrey Jordan and later changed to the Nile Provisional Government (NPG), did not succeed as it was affected by factionalism resulting in splits into Zande Separatist Movement (in the Zande Region), the Anyidi Revolutionary Government, the Sudan-Azania Government (in Eastern Sudan) and the Suer River Revolutionary Government (in the Western Equatoria Region) (O'Ballance 2000; Voll 1978).

In terms of conflict, Nimeiri's rule saw the intensification of the Anya-Nya offensive, especially after the formation of the South Sudan Liberation Movement (SSLM) in August 1971 led by Joseph Lagu. One cannot ignore the role of external players in the Sudanese conflict during this period. It has been stated, for example Israel is said to have trained Anya-Nya recruits, the South Sudanese exiled community in Middle East, Europe and the US assisted in arms purchase, and the Soviet Union delivered vast quantities of military equipment and armoured vehicles in the late 1960s and early 1970s (Metz 1997). 
Perhaps, credit should also be given to Nimeiri's government for engaging in peace talks after realizing that the conflict had claimed several lives, drained national resources, and arrested economic development (see Johnson 2014; Metz 1997; Voll 1978). These talks culminated into the signing of a peace agreement in Addis Ababa, Ethiopia on 27 February 1972 and ratified on 27 March 1972.

\subsection{Addis Ababa Accord/Agreement on the problem of the Sudan (1972)}

The Addis Ababa negotiations, which started in May 1971 between northern and southern delegations, and were facilitated by the then Ethiopian leader, Emperor Haile Selassie, together with the OAU, the United Nations High Commissioner for Refugees (UNHCR), Catholic Relief Agencies, the All Africa Council of Churches, and the World Council of Churches (WCC), with the Government represented by Abel Alier (Vice President and Minister of South Affairs) whilst the southern team led by Izbone Mendiri with Mading de Garang, representing SSLM and Colonel Frederick Magot, representing Anya-Nya Armed Forces (ANF), proved that with commitment to peace, all the conflict stakeholders in and outside Sudan had the capacity to dialogue (Abusharaf 2013: 77; O'Ballance 2000: 86).

The most important provisions of the Addis Ababa Agreement included the recognition of the south as a self-governing region (comprising the three provinces of Bahr al-Ghazal, Equatoria and Upper Nile). The agreement gave Southern Sudan political leadership and control through a House of Assembly, a High Executive Council (HEC), headed by a President who will be a Vice President of Sudan, and a Regional Development Corporation to steer socio-economic development in the southern region, all headquartered in Juba.

It also accorded southerners representation in the national parliament and all spheres of national government, and also guaranteed southerners their rights to fundamental human rights, religion, equal opportunity to education, employment, commerce, and profession as well as provisions governing issues of revenue management, national army composition (the formation of the Southern Command, a national force of 12000 army men with the south and the north contributing an equal number of officers, within 5 years), ceasefire terms, and refugee resettlement modalities (Addis Ababa Agreement 1972). However, the agreement stated that the central government in Khartoum retained control over three main aspects of governance, namely national defence, foreign policy and what the Government of Sudan (2015) termed "sovereignty matters", that is, socio-economic and development planning, international trade, and home affairs' issues of immigration and citizenship.

In examining the Addis Ababa Agreement, Badal (1976: 472) remarked that the agreement managed to take, "some of the heat out of the North-South conflict, allowing belligerent parties many opportunities to re-examine their 
attitudes toward each other". Indeed, the agreement brought relative peace to Sudan, which lasted for 10 years before the outbreak of another war (the Second Civil War) from 1982 to 2005. To protect it from future abrogation, the agreement was enshrined in the Constitution of Sudan through the Southern Provinces SelfGovernment Act of 1972, and its amendedment required a three quarters majority of the People's National Assembly and confirmation by a two-thirds majority in a referendum held in the three southern provinces.

The Addis Ababa Agreement's failure is also attributed to the failure of the government to smoothly integrate Anya Nya forces into the national army, especially the transfer of soldiers from the south to the north which was taken as driven by the desire to neutralize the power of the southern soldiers, and the recruitment, training and deployment of more northern soldiers than southerners against the Addis Ababa Agreement agreed ratio, hence counter mutinies in Juba (1974), Akobo (1975), and Wau (1974 and 1976), and other garrisons in Pibor, Pochalla, Rumbek, Kapoeta, and the Upper Nile; which ultimately resulted into the Anya Nya II movement (Shin, 2004). This was critical, especially considering that security had been the centre of power struggle during the peace negotiations (Alier in Shin 2004).

It has been argued that the Dinka domination in the newly autonomous southern Sudan political leadership structures resulted in discontentment amongst other southern tribes (Government of Sudan 2015). In June 1983 the Government abolished the elected regional government and its assembly in Juba, ostensibly to resolve ethnic imbalances, with Nimeiri as the GovernorGeneral and a few non-Dinka southerners were rewarded with "political posts and material largesse" in what Kebbede (1997:23) terms "a prurient effort to 'divide and rule' the region" through playing the southern leaders against each other. Two factors cannot be ignored here. Firstly, the politics of ethnic domination. Secondly, culpability of southerners to divide and rule tactics from Khartoum. These and other factors fomented conflict and contributed towards conflict renewal.

Be that as it may, most scholars attribute two key decisions by Nimeiri's Government as triggers of the 21 years long Second Civil War in Sudan, that is the introduction of Sharia law for the whole of Sudan and the attempted demarcation of the north-south boundary after the discovery of vast oil reserves by the USbased Chevron Corporation in the Bentiu District in 1978, Southern Kordofan and the Upper Nile in 1979, Unity Oilfields in 1980, Adar Oilfields in 1981, Heglig in 1982 (see Basha in Raftopoulus and Alexander 2006; Kebbede 1997; Machar 1995; O'Ballance 2000; Shin 2004; Voll 1978). The re-demarcation of the boundary, facilitated by the enactment of the People's Regional Government Act of 1980, was meant to ensure that the oil reserves in the southern region estimated at 5 billion barrels came under Northern territorial control, which contravened 
the Addis Ababa Agreement which stressed the sanctity of southern borders as inherited from the colonial government in January 1956.

Over and above that, the Northern Government declared plans to construct oil refineries in the north instead of refining it near the oilfields in the south. When this was resisted by the southerners, the Government of Sudan compromised by creating the Unity State to administer the oilfields (Iyob and Khadiagala 2006:88). This brings a resource control dimension to the Sudanese conflict. The imposition of Sharia law, through decrees referred to as the, "September Laws" in 1983, contravened the 1973 secular constitution of Sudan whilst the declaration of Arabic as, "the exclusive official language of the whole country" was an assault on Article 6 of the Addis Ababa Agreement, which stipulated that English was to be, "the principle language for the Southern Region" (Addis Ababa Agreement 1972). To Kebbede (1997:25), the imposition of Sharia laws was, "[t]he final rebuke to the Southern people" as those who opposed this were imprisoned and/ or executed.

Other than the two trigger issues of oil and imposition of Sharia law, the Second Civil War was also caused by the expropriation of farming land in the south by government and it's tempering with the autonomy of the southern region. In pursuit of a capitalized export-oriented agriculture initiative to turn Sudan into the "bread basket" of the Middle East; the Government of Sudan, complemented with funding from pro-sectarian parties' Islamic banks, facilitated the expansion of large-scale mechanized farming into the southern region, especially around the Upper Nile and Southern Kordofan provinces, thereby taking away farming and grazing lands from indigenous farmers and native pastoralists which all attracted "resentments and hostilities" in the south (see Kebbede 1997:23).

Economic decline is also argued to have contributed to the rising forces behind Anya Nya II uprisings. Nimeiri initially well managed the economy through a strategic foreign policy as he shifted alliance from the Soviet Union to the West, thereby attracting investments and financial assistance (Kebbede 1997). Through these efforts, Sudan is reported to have received, "the largest US economic and military aid in Africa after Egypt for its support of the Camp David Accords between Israel and Egypt in the late 1970s", whilst international leaders collectively, "poured more than US\$2 billion into Sudan's agriculture between 1975 and 1985" (Voll cited in Kebbede 1997:20). However, the economic progress was reversed due to world recession, rising oil prices, economic mismanagement, corruption, and the Economic Structural Adjustment Programme (ESAP), resulting in unemployment and widespread poverty, which all provoked uprisings. As the southern Sudan was less developed, it was always more affected by economic shocks. 


\subsection{The Second Civil War in Sudan (1983-2005)}

The above discussed factors all angered Southerners giving rise to Anya Nya II, or the Second Civil War, in 1983 initially in Kordofan, Bar el-Ghazal and the Upper Nile. Rebellions were organized under the Sudan Peoples' Liberation Movement/ Army (SPLM/A), which had been renamed from SSLM, in 1983, under the leadership of Dr John Garang De Mabior, whose agenda was, to create a "New Sudan" with a reformed and plural political system. The chief objective of the $\mathrm{SPLM} / \mathrm{A}$, as stated in its manifesto was "to prevent Sudan from the inevitable disintegration by providing a correct solution to the nationality and religious questions within the context of a united Sudan and establish a new cultural order within a new Sudan" (Basha in Raftopoulus and Alexander 2006: 13).

During the course of the Second Civil War, from 1983 to 2005, Nimeiri was deposed by a military coup on 6 April 1985, paving way for civilian governments led by Al-Jazuli Dafállah (Prime Minister from 1985-1986) and Sadiq al-Mahdi (Prime Minister from 1986-1989). Lieutenant General Omar Hassan Ahmad alBashir and his National Islamic Front (NIF) Party removed Sadiq al-Mahdi through a military coup, backed by Hassan el-Turabi and the Muslim Brotherhood, thereby assuming office on 30 June 1989.

It is Bashir's domestic and foreign policy, which failed to restore peace and stability in Sudan. His reinforcement of Sharia, alleged human rights abuses, the NIF's pan-Islamist stance which claimed to resist the US', "reconquest of the Islamic world", and the SPLM/A's diplomatic offensive in the region and beyond resulted in the isolation of Sudan, especially by the Western world as the US suspended bilateral trade, foreign assistance, whilst the International Monetary Fund (IMF) suspended Sudan's membership (Iyob and Khadiagala 2006: 102). This isolation was to continue even into the early $21^{\text {st }}$ century, when Sudan was accused of harbouring terrorist groups after Osama bin Laden stayed in the country in the early 1990s and was later implicated as one of the architects behind the September 11 Attacks (see Bergen 2001; Deng et al 2008; Government of Sudan 2015). This left it with limited option, other than engaging the Eastern Asia countries, namely China, Malaysia and others. Bashir's government, especially from the early 1990s, according to Khalid (2010: xxviii), "ceased to see Sudan's historic fratricidal conflict as a civil war" and, "recreated it into a jihad (holy war)" via the deployment of the Peoples' Defence Forces (PDF) troops with, "Northern adversaries" seen as mujahideen (fighters for Allah's cause). Those who died were seen as Shuhada (martyrs), "who would reside in heaven and be instantly rewarded".

It attempted to turn back the clock through spreading Islamization and Arabization in Sudan. Bashir also divided Sudan into 9 states, 66 provinces and 281 local government areas on the pretext of devolving power and closing 
the north-south gap, much to the chagrin of southerners. The blocking of international aid to reach southerners by the Khartoum Government resulted in humanitarian crisis and famine up until the collaboration between the UN, the Government of Sudan and SPLM/A to establish Operation Lifeline Sudan in 1989 for UN agencies and other NGOs to extend food aid to drought-stricken and warravaged Southerners (Iyob and Khadiagala 2006; Schafer 2007).

In the midst of civil war, attempts were made to bring together the southern rebel leaders and the Government of Sudan for peace talks. It should be stressed that the positions of the southerners, fronted largely by the SPLA, were evolving and at times differing amongst the southerners, hence the conflict was characterised by factionalism, ethnicism, disagreements and splinters. For instance, in August 1991 the SPLM/A split into two factions (one led by John Garang (Torit or Mainstream) and the other led by Riek Machar (Nasir or United); and in 1994 the SPLM/A United split again into two (to form the Southern Sudan Independence Movement/Army (SSIM/SSIA), led by Riek Machar, and the SPLM/A United, led by Lam Akol, in the West Central Upper Nile). However, the uniting cause remained the fight against the Government in Khartoum.

\subsection{Substantive Peace Talks/Negotiations (1993 - 2005)}

Several attempts were made by various actors in the region and beyond to resolve the conflict between the Government of Sudan and the southern political movements led by the SPLM/A. The UN blames the, "immense complexities of the war and the lack of political will" as stumbling blocks that prevented an early resolution to the conflict (UN 2016: np). Of course, each of the national, regional and international parties to the Sudanese conflict has always pursued its own interests throughout the peace negotiation process.

The Koka Dam Declaration, a list of demands proposed at a Conference at Koka Dam in Ethiopia on 20 March 1986 held between the SPLM/A and the Umma Party and representatives of professional organizations and trade unions, were used as the basis of engagement in future peace talks. Peace talks chaired by Jimmy Carter, the former US President, between the Government of Sudan's President Bashir and SPLM/A's John Garang in December 1989 in Nairobi, Kenya; broke down resulting in the continuation of civil war (Schafer 2007). The US Assistant Secretary of State, Herman Cohen and the National Council of Churches also attempted negotiations between the two in Nairobi, Kenya in 1990 and 1991 respectively, but they were unsuccessful as the Government could not compromise on Sharia laws and the SPLM/A-demanded, "secular and broadbased national unity government" (Iyob and Khadiagala, 2006:93).

The involvement of the Inter-Governmental Authority on Drought and Development (IGADD), which later transformed into the Inter-Governmental 
Authority on Development (IGAD), as mediators in the conflict from 1993, was influential. The US and the European Union (EU) were involved in bolstering the peace talks through the US deployment of Ambassador Melissa Wells as a Special US Envoy to Sudan and the EU's launch of "Friends of Sudan and Uganda" which convened talks between President Yoweri Museveni and Bashir in Australia in May 1994, "to ease bilateral tensions and remove all obstacles to a peace settlement" (Iyob and Khadiagala 2006:106).

A Peace Charter signed between Machar's SSIM and Col Kerubino Kuanyin Bol's SPLM/A-United had agreed to preserve the unity of Sudan but the pact was rejected by Garang's SPLA-Torit faction (O'Ballance 2000). However, all the other SLPM/A splinter groups, except Garang's SPLM/A-Torit faction, re-united themselves through the Peace Agreement of 1996 and resolved that their position was self-determination for the south, suspension of Sharia law and amnesty for their members (O'Ballance 2000).

As war raged on, the Abuja I Talks and Abuja II Talks of 1992 and 1993 respectively were brokered by Nigerian President and the then OAU Chairman, Ibrahim Babangida, but there was no compromise between the two parties as Garang insisted on secession and a secular government whilst President Bashir preferred southern autonomy under an Islamic central government with fierce contention over power and resource-sharing arrangements (Verney 1995). This forced the US to consider diplomatic sanctions against Sudan through the "Frontline Strategy" in which the Clinton Administration engaged Eritrea, Ethiopia and Uganda to isolate Sudan, which they did in December 1994 and April 1995 and 1995 respectively (Iyob and Khadiagala 2006). These were followed by UNSC sanctions on Sudan in 1996, the withdrawal of embassy officials by the US, and the provision of weapons to Eritrea, Ethiopia and Uganda by the US as the SPLM/A launched their attacks from bases in these countries.

Later IGADD further facilitated talks between the Government of Sudan and SPLM/A, mediated by Nelson Mandela, on 29 October 1997 and November 1998, but did not succeed. The Egypt-Libya Initiative which started in 1997, through to 2001, could not yield results. The peace talks brokered in Switzerland in January 2002 by John Danforth, the US Special Envoy to Sudan, achieved ceasefire pacts and paved way for IGAD supported mediation with observers from the troika of UK, Norway and Italy. This, together with the enactment of the Sudan Peace Pact in October 2002 by the US, coupled with the US' assumption of presidency in the UNSC, brought progress to the negotiations, which culminated into the CPA ratified in Naivasha, Kenya 2005.

The negotiations for peace in Sudan were a protracted process. This is understandable, especially if one consideres the complex nature of the conflict, its involvement of various players with divergent and seemingly incompatible interests. The main parties to the conflict, that is, the Government of Sudan, the 
northern political parties, the southern political parties, IGADD Member States, the US, AU, UN, EU Member States, China, Libya and Egypt all had their individual interests and motives. As Schafer (2007: 7) aptly noted, the Government of Sudan represented northern interests for peace and security, oil, resources, Islamic law, and power (political and socio-economic) whilst the southern political movements wanted peace, self-governance, freedom of religion, recognition, economic growth/development, oil, resources, equality and representation in government.

On the other hand, IGAD, the AU and the UN were motivated by the desire for peace, regional security, legitimacy, trade relations, curbing terrorist threats, regional development, power and border control, whilst the US, the EU, and China were interested in thwarting terrorist cells in Sudan, ensuring regional influence, border control, trade relations and securing oil/resources (Schafer 2007: 8-9). To lyob and Khadiagala (2006:124), "the convergence of multiple actors helped the process as they played complementary and oftentimes competitive roles, to steer the complex process and help parties to gradually rediscover points of agreements".

This made the whole peace negotiating process difficult, as progress would only be defined by the extent to which parties were willing and ready to compromise.

\subsection{The Comprehensive Peace Agreement and Government of National Unity in Sudan (2005-2011)}

Through IGAD mediation, the CPA's six Protocols were signed between the Government of Sudan and the SPLM/A. These included the Protocol of Machakos signed in Machakos, Kenya; on 20 July 2002; and Protocol on Security Arrangements signed in Naivasha, Kenya on 25 September 2003; Protocol on Wealth-sharing; Protocol on Power-sharing, and The Protocol on the Resolution of the conflict in Southern Kordofan/Nuba Mountains and the Blue Nile States, and The Protocol on the Resolution of Conflict in Abyei, all signed in Naivasha, Kenya on 26 May 2004. One of the most significant provisions of the Protocol of Machakos stipulated that the southerners would conduct a referendum to decide whether they would secede from Sudan or remain part of a united Sudan after the 6 -year interim period.

One can argue that the non-implementation of most of the protocols to the CPA also further strengthened the resolve by the southern Sudanese to secede. For instance, The Protocol on Power-sharing provided for equitable regional representation in the Government of National Unity (GoNU) and the formation of a separate Government of Southern Sudan (GoSS) with government positions to be shared based on a 70\%:30\% ratio in favour of the NCP in the northern 
states, and 70\%:30\% in favour of the SPLM/A in southern states, whilst the ratio of 55\%:45\% would apply in Abyei, the Blue Nile and the Nuba Mountains (CPA 2005), however, in actual fact, northern Sudanese remain dominant across all institutions of governance.

In addition, whilst demobilization, disarmament and reintegration (DDR) programmes were to be implemented under UN monitoring, and the SPLA was given eight months to withdraw from the north, whilst SAF troops were to be redeployed from the south to north within two years (CPA 2015), the implementation of this was minimal and therefore unsuccessful as all armies in the conflict were neither willing nor ready to downsize their forces for security reasons (Small Arms Survey 2012).

Even more disturbing, the Protocol on Wealth-sharing had provided that $2 \%$ of oil revenues would be channelled to the oil producing states in the south in proportionality to their output, whilst the remainder would be equally shared between the national government and GoSS. Further, in Abyei, The Protocol on the Resolution of Conflict in Abyei had resolved that oil revenue was to be shared between the north and the south based on a 50\%:42\% ratio respectively, with the remaining $2 \%$ allocated to the Ngok Dinka, Misseriya and Bahr al-Ghazal people, whilst $1 \%$ each would be allocated to the South Kordofan State and the West Kordofan State. All this was violated as the GoSS was involved in disputes that resulted in disruption of oil production and its exportation.

Whilst it led to peace after a taxing war regarded as the longest running conflict in Africa, the CPA has been criticized as, "a narrow elite pact between NCP and SPLM/A", which excluded other parties across Sudan (lyob and Khadiagala 2006:174). Rogier (2005: vii) agrees, asserting that although it "undoubtedly represents a historic achievement" in ending the war, and, "provides for a fair settlement of the Southern Sudanese", the CPA however "fails to be 'comprehensive' in its representation", as it is mainly restricted to two political parties.

For the duration of the implementation of the CPA in the interim period between 2005 and 2011, there has been a struggle for power between the SPLM/A and NCP Leaders in Khartoum, over and above the in fighting within the SPLM/A itself. The SPLM/A withdrew from the GoNU in October 2007, alleging that the NCP dominated all structures of government, and later announced its comeback in December 2007. There were also delays in undertaking the census stipulated in the CPA, and commissions, that were provided for to champion economic development were also formed late and did not actualize their work whilst the redeployment of the SAF and the SPLM/A also delayed until 2008 resulting in tensions. 


\subsection{Referendum and secession of South Sudan (January-July 2011)}

As mandated by the CPA, the referendum for southerners, to decide on selfdetermination, was conducted from 9-15 January 2011. According to the South Sudan Referendum Commission (SSRC), as cited in Dagne (2012:1), 3,9 million were registered to vote, including those residing in other countries, and an estimated 3,8 million voted. Of these, 98,83 voted for secession and 1,1\% voted for unity in a plebiscite endorsed by international community and Sudan as free and fair (SSRC as cited in Dagne 2012:1). This was way above the 60\% turnout threshold that was needed for a valid vote as stipulated by the Southern Sudan Referendum Act of 2009. Thus, South Sudan seceded from Sudan on 9 July 2011.

\section{REFLECTING ON THE CAUSES OF THE SOUTH SUDANESE SECESSION: WHAT LESSONS CAN BE LEARNT?}

From the refection of the root causes of South Sudanese secession, it can be deduced that seven key factors were influential in contributing towards the clamour for, and eventual implementation of, secession.

Firstly, the pre-colonial practices of slavery may have marked the initial regional divide between northern Sudan and southern Sudan. Annual raids on the southerners by the northerners, which resulted in the capture of countless thousands of southern Sudanese to sale as slaves to Arab slave traders, Europeans, and Egyptians, definitely made southerners to declare the northerners as enemies. Of course, this practice of slavery continued even during the TurkoEgyptian rule between 1821-1882.

Secondly, the colonial administrations' insistence on policies rooted in entrenching attitudes and perceptions of hatred, mistrust and hostilities between northern and southern Sudanese. The Turko-Egyptian rule (1821-1882) and the Anglo-Egyptian Condominium (1899-1956) nurtured and watered the seeds of north-south division and secession in Sudan.

Thirdly, the failure by the British colonial administration to design and facilitate a smooth transitional process from colonialism to independence, left a ticking time bomb in Sudan. In light of outstanding grievance for southern autonomy, it was prudent for the British to find a lasting and sustainable solution or resolution to the southern question. Unfortunately, this failure, against the background of a deeply divided society, presented a challenge to post-colonial governments in Sudan. From the above, a clear lesson for African countries is the need to comprehensively address the vestiges and residue of colonialism that continue to entrench the socio-economic and political systems of most countries 
on the continent. National institutions, laws and policies should embed a culture of unity, national consciousness, integration and cohesion.

Fourthly, post-colonial governments' collective failure to implement policies that foster national unity, integration, social cohesion, and stability contributed to conflict. Almost all the post-independence leaders in Sudan, from Khalil to Bashir, adopted policies that perpetuated marginalization, regional imbalances, under-representation, exclusion, inequality, suppression and oppression of citizens based on regionalism, religion, ethnic groups and political affiliation. Efforts to ensure unity in diversity were forced, based on religious and racial ideology such as Arabism and Islamization. There was no genuine commitment to adherence to the sacrosanct principles of non-discrimination, inclusion and human rights. This presents one of the most fundamental lessons to African governments. Most secessionist movements on the continent seem to converge on the grievances of marginalization, regional imbalances, underrepresentation, exclusion, inequality, suppression and oppression of citizens based on regionalism, religion, ethnic groups and political affiliation. For instance, this is the case with the Movement for the Actualization of the Sovereign State of Biafra in Nigeria, the Movement of Democratic Forces of Casamance (MFDC) in Senegal, the Southern Cameroons Independence Restoration Movement in Cameroon, the Ogaden National Liberation Movements and Oromo Independence Movements in Ethiopia, the Kabylian Movement for Self-Determination in Algeria, and the Mombasa Republic Council in Kenya, among many others.

Fifthly, the absence of strong and independent institutions of governance, as well as the involvement of the military in civilian governance, can be cited as a cause of conflict and its culmination into secession. This is evidenced in a series of coups that were repleted in Sudanese history in 1958, 1969, 1985, and 1989; as well as failed coups in 1961 and 1971. A system of government that does not clearly define state-military relations makes the society susceptible to conflict. In the same vein, the national assembly in Sudan had not manage to play its oversight function. Instead, it had been used and abused to pass laws that perpetuate societal divisions, inequality, injustice and conflict. For African states, there is need for commitment to bolstering state institutions and making them immune from interference and elite capture as this can be a genesis for secessionist conflicts.

Sixthly, another root cause of secession was the neglect of principles of good governance by the successive regimes in Sudan. In the overall, there has been very little democracy, transparency, public participation, responsiveness, accountability, equity and inclusiveness in governance. There was very little consultation before the adoption of most decisions that affected citizens, especially the southerners, whilst at the same time successive regimes in Sudan chose to constrain civil liberties, impose religion on citizens, and flout peace 
agreements with impunity and impudence. African countries should learn that it is through democratic arrangements and genuine citizen participation that acceptable models of governance, such as federalism, confederation, consociationalism, a government of national unity (GNU), or any appropriate alternative, can be identified and implemented to ensure unity, peace and stability.

Lastly, the failure of post-colonial Sudanese governments to ensure inclusive development across all regions, and ensure that its natural resources, specifically oil, is extracted for the benefit of all citizens, has not been one of the root causes of conflict. For instance, instead of designing a fair system of oil revenue sharing, after the discovery of vast oil reserves by the US-based Chevron Corporation in the Bentiu District in 1978, Southern Kordofan and Upper Nile in 1979, Unity Oilfields in 1980, the Sudanese Government, then under Nimeiri, chose to enact the People's Regional Government Act of 1980, which facilitated the re-demarcation of the north-south boundary so as to ensure that the oil reserves in the southern region come under northern territorial control. It is of cardinal importance that natural resource-endowed countries in Africa develop innovative, fair and just mechanisms to extract benefits from the exploitation of their resources for the socio-economic empowerment benefit of their citizens.

The above summarization presents very instructive lessons to African countries at this point in time, especially considering the prevalence of secessionist movements and conflicts in several countries, which threaten national stability, unity, development, regional peace and security.

\section{CONCLUSION}

This article has analytically traced the root causes of the Sudanese conflict. It has analysed how different political and socio-economic factors in the pre-colonial, colonial and post-colonial Sudan have caused, perpetuated and sustained conflict within Sudan. It can be noted that the Sudanese conflict was a result of interplay of a motley of factors, namely the colonial legacy of geographical, socioeconomical and political separation; economic marginalization by post-colonial governments; ethnicization politics or politicization of ethnicity; competition over scarce resources, religious intolerance, and this struggle for power, among others. The lessons presented are key to African governments to learn in order to sustainably prevent, manage and resolve secessionist conflicts. 


\section{REFERENCES}

Abusharaf, RM 2013. "Seeds of secession". Transition: An international review, 110: $73-89$.

Ahmad, AGM 2010. Sudan peace agreements: Current challenges and future prospects. Chr. Michelsen Institute.

Alier, A 1973. The Southern Sudan Question. In: Dunstan M. Wai, ed. The Southern Sudan: The problem of national integration. London: Frank Cass and Company Ltd, pp.11-28.

Arkell, AJ and HA MacMichael 1961. A history of the Sudan: From the earliest times to 1821. London: Athlone Press.

Badal, RK 1976. "The rise and fall of separatism in Southern Sudan". African Affairs, 75(301): 463-474.

Basha, S 2006. "Civil wars: Multiple causes, multiple parties - One 'Comprehensive' Agreement?" In: Raftopoloulos, Brian and Alexander, Karin, eds. Peacebuilding in the balance: The crisis in Sudan. Cape Town: Institute for Justice and Reconciliation.

Bergen, PL 2002. Holy war, Inc.: Inside the secret world of Osama bin Laden. New York: Simon and Schuster.

CIA World Factbook 2015. "South Sudan natural resources", 30 June. Online, http://www.indexmundi.com/south_sudan/natural_resources.html, accessed 5 May 2016.

Dagne, T 2012. The Republic of South Sudan: opportunities and challenges for Africa's newest country. CRS Report for Congress Prepared for Members and Committees of Congress. Congressional Research Service.

Daly, MW 2003. Imperial Sudan: The Anglo-Egyptian Condominium 1934-1956. New York: Cambridge University Press.

Deng, AL, BN Chol and B Youree 2008. Courageous journey: Walking the lost boys' path from the Sudan to America. New Jersey: New Horizon Press.

Deng, RDDA 1994. The politics of two Sudans: the south and the north, 1821-1969. Nordic Africa Institute.

Fadlalla, MH 2004. Short history of Sudan. New York: iUniverse Inc.

Government of Sudan 2015. "Sudan under occupation. Ministry of Foreign Affairs". Online, http://mofa.gov.sd/new/en/more.php?main_id=7andsub_ id =58andid=7, accessed 2 May 2016.

Gurtong Trust 2016. "Full minutes of the Juba Conference 1947". EP/SCR/1.A.5/1. Juba, 21st June 1947. Online, https://paanluelwel2011.wordpress.com/tag/ minutes-of-juba-conference-1947/? iframe=true\&preview=true $/$ feed $/$, accessed 25 April 2018. 
Holt, PM and MW Daly 2014. A history of the Sudan: from the coming of Islam to the present day. London: Routledge.

Iyob, R and GM Khadiagala 2006. Sudan: The elusive quest for peace. Boulder, CO: Lynne Rienner, for the International Peace Academy.

Johnson, DH 2011. The root causes of Sudan's civil wars: Peace or truce? Kampala: Fountain Publishers.

Johnson, DH 2014. "The political crisis in South Sudan", African Studies Review 57(3): 167-174.

Kebbede, G 1997. "Sudan: The north-south conflict in historical perspective." A Journal of African and Afro-American Studies 15(3): 15-45.

Khalid, M 2007. "Historical landmarks in the condominium period and the colonial role in the creation of two Sudans, 1898-1956". In: Peter Gwynvay Hopkins, ed. The Kenana Handbook of Sudan, pp.187-196.

Machar, TD 1995. South Sudan: A history of political domination. A case of selfdetermination, Africa Studies Center, University of Pennsylvania.

Metz, HC 1991. A country study: Sudan. In Federal Research Division Library of Congress, Washington DC: Federal Research Division Library of Congress.

Musa, AM 2010. "Marginalization and ethnicization in the Sudan: How the elite failed to stabilize a diverse country", Contemporary Arab Affairs, 3(4): 551562.

O'Ballance, E 2000. Sudan, civil war and terrorism, 1956-1999. New York: Macmillan Press.

Okojie, OS 2013. "Between secession and federalism: The independence of South Sudan and the need for a reconsidered Nigeria", Global Business and Development Law Journal 26(2): 415-474.

Powell, ET 2003. A different shade of colonialism: Egypt, Great Britain, and the mastery of the Sudan, Vol. 2, Berkeley: University of California Press.

Schafer, LA 2007. "Negotiating the North/South conflict Sudan's Comprehensive Peace Agreement", ISS Paper 148, July 2007. Online, http://journals.co.za/ content/ispaper/2007/148/EJC48807, accessed 26 June 2015.

Sharkey, HJ 2003. Living with colonialism: Nationalism and culture in the AngloEgyptian Sudan, Vol. 3, Berkeley: University of California Press.

Shinn, DH 2004. "Addis Ababa Agreement: was it destined to fail and are there lessons for the Current Sudan Peace Process?", Annales d'Ethiopie 20(1): 239-259.

Small Arms Survey 2012. "Disarmament, demobilization, and reintegration. Human Security Baseline Assessment for Sudan and South Sudan". Online, http://www.smallarmssurveysudan.org/facts-figures/ddr.html, accessed 22 February 2018. 
"The Addis Ababa Agreement on the problem of South Sudan". Online, https:// peacemaker.un.org/sudan-addisababa-southsudan72, accessed 26 April 2018.

United Nations 2015. "United Nations Geospatial Information Section". Online, http://www.un.org/Depts/Cartographic/map/profile/sudan.pdf, accessed 12 February 2016.

United Nations 2011. "Closure of United Nations Mission in Sudan". Available at: https://unmis.unmissions.org/comprehensive-peace-agreement, accessed 26 June 2015.

Voll, J.O 1978. Historical dictionary of the Sudan. Metuchen, N.J.: Scarecrow Press.

Ylonen, A 2008. "Political marginalization and economic exclusion in the making of insurgencies in Sudan". In: Magnus Oberg and Kaare Ostrom, eds. Resources, governance and civil conflict. London: Routledge, pp.125-146. 